UDK 577.1 : 61

ISSN 1452-8258

J Med Biochem 41: 53-61, 2022

\title{
INTERFEROGRAMS PLOTTED WITH REFERENCE CHANGE VALUE (RCV) MAY FACILITATE THE MANAGEMENT OF HEMOLYZED SAMPLES
}

\section{INTERFEROGRAMI PREDSTAVLENI SA PROMENOM REFERENTNE VREDNOSTI (RCV) MOGU POTPOMOĆI ORGANIZACIJI HEMOLIZOVANIH UZORAKA}

\author{
Kamil Taha Uçar ${ }^{1}$, Abdulkadir Çat ${ }^{2}$, Alper Gümüş ${ }^{3}$, Nilhan Nurlu $^{2}$ \\ ${ }^{1}$ Bilecik Public Health Laboratory, Medical Biochemistry, Bilecik, Turkey \\ ${ }^{2}$ Istanbul Gaziosmanpasa Training and Research Hospital, Medical Biochemistry, Istanbul, Turkey \\ ${ }^{3}$ Basaksehir State Hospital, Medical Biochemistry, Istanbul, Turkey
}

\section{Summary}

Background: The European Federation of Clinical Chemistry and Laboratory Medicine (EFLM) Working Group for Preanalytical Phase (WG-PRE) have recommended an algorithm based on the reference change value $(\mathrm{RCV})$ to evaluate hemolysis. We utilized this algorithm to analyze hemolysis-sensitive parameters.

Methods: Two tubes of blood were collected from each of the 10 participants, one of which was subjected to mechanical trauma while the other was centrifuged directly. Subsequently, the samples were diluted with the participant's hemolyzed sample to obtain the desired hemoglobin concentrations $(0,1,2,4,6,8$, and $10 \mathrm{~g} / \mathrm{L})$. ALT, AST, $K$, $\mathrm{LDH}, \mathrm{T}$. Bil tests were performed using Beckman Coulter AU680 analyzer. The analytical and clinical cut-offs were based on the biological variation for the allowable imprecision and RCV. The algorithms could report the values directly below the analytical cut-off or those between the analytical and clinical cut-offs with comments. If the change was above the clinical cut-off, the test was rejected. The linear regression was used for interferograms, and the hemoglobin concentrations corresponding to cut-offs were calculated via the interferograms.

Results: The RCV was calculated as $29.6 \%$ for ALT. Therefore, ALT should be rejected in samples containing $>5.9 \mathrm{~g} / \mathrm{L}$ hemoglobin. The RCVs for AST, K, LDH, and T. Bil were calculated as $27.9 \%, 12.1 \%, 19.2 \%$, and $61.2 \%$, while the samples' hemoglobin concentrations for test rejection were $0.8,1.6,0.5$, and $2.2 \mathrm{~g} / \mathrm{L}$, respectively.

\section{Kratak sadržaj}

Uvod: Radna grupa za preanalitičku fazu (WG-PRE) Evropske Federacije za kliničku hemiju i laboratorijsku medicinu (EFLM) preporučila je algoritam koji se zasniva na promeni referentne vrednosti (RCV) za procenu hemolize. Mi smo koristili ovaj algoritam za analiziranje osetljivih hemolizovanih parametara.

Metode: Uzete su dve epruvete krvi od svakog od 10 učesnika, jedna koja je bila predmet mehaničke traume a druga je direktno centrifugirana. Istovremeno uzorci su bili razblaženi sa hemolizovanim uzorcima učesnika da bi se dobile željene koncentracije hemoglobina $(0,1,2,4,6,8$ i $190 \mathrm{~g} / \mathrm{L}$ ). Analiziranje ALT, AST, K, LDH, T. Bil je izvedeno primenom Beckman Coulter AU680 analizatora. Analitičke i kliničke cut-off vrednosti bile su zasnovane na biološkoj varijaciji za dozvoljivu nepreciznost i RCV. Algoritmi su odgovarali direktno vrednostima ispod kliničke cut-off ili one između analitičke i kliničke cut-off. Ako je promena bila iznad kliničke cut-off test je odbačen. Linearna regresija je korišćena na interferograme i koncentracije hemoglobina koje su odgovarale cut-off vednostima izračunatih preko interferograma.

Rezultati: RCV je izračunat kao 29,6\% za ALT. Prema tome potrebno je odbaciti uzorke za ALT koji su imali $>5,9 \mathrm{~g} / \mathrm{L}$ hemoglobina. RCV za AST, K, LDH i T. Bil izračunati su kao $27,9 \%, 12,1 \%, 19,2 \%$ i $61,2 \%$, dok su uzorci sa koncentracijom hemoglobina za odbacivanje testa bili $0,8,1,6$, 0,5 i $2,2 \mathrm{~g} / \mathrm{L}$.

Address for correspondence:

Kamil Taha Uçar

Bilecik Public Health Laboratory

No: 1, Guniz St., Bahcelievler, Bilecik, 11000, Turkey

Phone number: +905355055359

e-mail: drktahaucar@hotmail.com 
Conclusions: Algorithms prepared with RCV could provide evidence-based results and objectively manage hemolyzed samples.

Keywords: hemolysis, interference, preanalytical phase, laboratory errors, reference change value

\section{Introduction}

The International Organization for Standardization (ISO) has established that laboratory errors may arise at every point related to the laboratory in the process, from the test request to diagnosis and treatments interrelated to test results (1). This comprehensive definition showed that the laboratory's responsibilities are not only restricted to analyze the test and report its results. Nowadays, when laboratory results are considered crucial in clinical decisions, laboratories have a significant role, directly or indirectly, in the diagnosis and treatment of patients in many aspects (2). Thus, laboratory errors should be handled with a holistic approach, evaluated, and fixed (3).

Most of the errors evident in laboratories arise from the preanalytical process (4). Notably, the most common problem in this process is that of inappropriate samples (5). Among inappropriate samples, hemolyzed samples are the most common. Evaluation of all samples sent to the laboratory in a previous study, revealed that $2.2 \%$ of them were hemolyzed samples (6). Among samples accepted from emergency departments, up to $30 \%$ have been reported to be hemolyzed (7). Hemolysis can be in vivo and in vitro. In vivo hemolysis occurs during various diseases or treatments and constitutes only $2 \%$ of all hemolyzed samples accepted to the laboratory (8). In vitro hemolysis is almost the sole cause of hemolyzed samples encountered in laboratories and is caused by the following: blood collection process, sample handling process, sample processing process, and individual differences (9).

Hemolysis can be evaluated using two methods. The first is the classical method based on the technician's visual assessment. The visual evaluation method is discouraged because of its subjectivity and low reproducibility. Even if the color indicator charts with varying degrees of hemolysis, sample photographs are used for evaluation; this method's reliability and sensitivity are relatively low $(10,11)$. The second method uses hemolysis index ( $\mathrm{H}$-index), a tool that enables estimating the sample free hemoglobin $(\mathrm{Hb})$ concentration using automated systems. The $\mathrm{H}$-index can report the degree of hemolysis to both the laboratory specialist and physician. Therefore, it can enable the evaluation of the test results affected by hemolysis in the analyzed sample. Automated systems are reportedly more reliable than visual evaluation in determining hemolysis, and therefore, it is recommended for use instead of the visual method (12). Currently, the management of hemolyzed samples involves applying four options according to the hemolysis level, as follows: analysis of the sample followed by reporting the result; reporting the result and its interpretation; rejection based on the test; thorough sample rejection (13). For correct implementation, the serum index should be determined based on the test for the management of hemolysis.

The C56-A guideline of the Clinical and Laboratory Standards Institute (CLSI) recommends that interference
Zaključak: Algoritimi pripremljeni sa RCV mogu da obezbe rezultate zasnovane na dokazima i objektivno procene hemolizovane uzorke.

Ključne reči: hemoliza, interferencija, preanalitička faza, laboratorijske greške, promene referntnih vrednosti

studies should first be carried out by in vitro diagnostic (IVD) manufacturers and that the laboratories should design, as well as use, their algorithms. It also states that the reference change value (RCV) can be used as the allowable total error criterion for interference studies (14). Fraser stated that when the interfering effect of the substance on the test result exceeds the RCV, it could change the actual level of the measured analytes, with a clinically significant difference (15). The entire procedure was presented in an opinion letter that was recommended for clinical biochemistry tests published by the European Federation of Clinical Chemistry and Laboratory Medicine (EFLM) Working Group for Preanalytical Phase (WG-PRE) in 2018 (16). The EFLM WG-PRE has proposed an algorithm in line with this data to evaluate hemolysis interference for clinical chemistry tests. Interferograms were created by adding the allowable analytical coefficient of variation (CV) values and RCV as evaluation criteria after graphs were drawn by calculating the percentage change according to the $\mathrm{Hb}$ concentration for each test. Recent studies recommend a new algorithm that allows the interpretation of the test result through interferograms (12).

In this study, we aimed to develop algorithms to be used in the alanine aminotransferase (ALT), aspartate aminotransferase (AST), lactate dehydrogenase (LDH), potassium (K), and total bilirubin (T. Bil) tests for our laboratory, with respect to these suggestions, and to compare the data obtained with the manufacturer's statements.

\section{Materials and Methods}

This study was performed at the Medical Biochemistry Laboratory of the Gaziosmanpasa Training and Research Hospital, with the approval of the local ethics committee (decision date \& number: April 10, 2019-56), in accordance with the Declaration of Helsinki. The study was explained to all volunteers and then informed consent was obtained.

\section{Study design and sample preparation procedure}

The sample size was determined to be 10 people, as per the CLSI EP 07A2 guideline. Acute or chronic disease, regular medication use, bleeding disorder, and pregnancy were selected as the exclusion criteria. Two tubes of blood were collected from 10 apparently healthy volunteers aged between 18 and 50 years. A single experienced phlebotomist was appointed to perform blood collection, to avoid hemolysis caused by phlebotomy. The samples were collected in the collection tubes (BD Barricor $5.0 \mathrm{~mL}$, $13 \times 100$ mm, Becton, Dickenson and Company, NJ, USA) using the blood collection device (BD Vacutainer Holder, Becton, Dickenson and Company, NJ, USA) equipped with a needle (BD Vacutainer Eclipse 21G, BD-Belliver Industrial Estate, Plymouth PL6 7BP, UK). 
One of the paired tubes was centrifuged without any intervention to obtain the hemolysis-free samples. The blood from the other tube was passed through the needle 10 times using an injector to achieve mechanical hemolysis (12). The mechanical trauma method was preferred to obtain samples similar to hemolyzed samples sent to the laboratory. This method ensured that the hemolyzed sample contains leukocytes and thrombocytes (13). Subsequently, the tubes were centrifuged at $2000 \times g$ for 10 min following the manufacturer's recommendation.

Free $\mathrm{Hb}$ concentrations were measured in the separated plasma samples by the spectrophotometric method using the auto hematology analyzer (Mindray BC 6800,
Shenzhen Mindray Bio-Medical Electronics Co., China; imprecision of $\mathrm{Hb}$ : $1.0 \%)$. It was confirmed that one of the samples had an $\mathrm{Hb}$ concentration of $0 \mathrm{~g} / \mathrm{L}$, while the other had a $\mathrm{Hb}$ concentration $>10 \mathrm{~g} / \mathrm{L}$. To obtain samples with the desired free $\mathrm{Hb}$ concentrations $(1,2,4,6,8$, and 10 $\mathrm{g} / \mathrm{L})$, the hemolyzed samples were diluted with the hemolysis-free sample of the same volunteer. The samples were prepared individually for each volunteer, thus preventing dilution bias and inter-individual differences from affecting the values obtained. After obtaining the diluted samples, each sample was analyzed duplicate on the Mindray BC 6800 analyzer to confirm the desired $\mathrm{Hb}$ concentration. The process for sample preparation is shown in Figure 1.

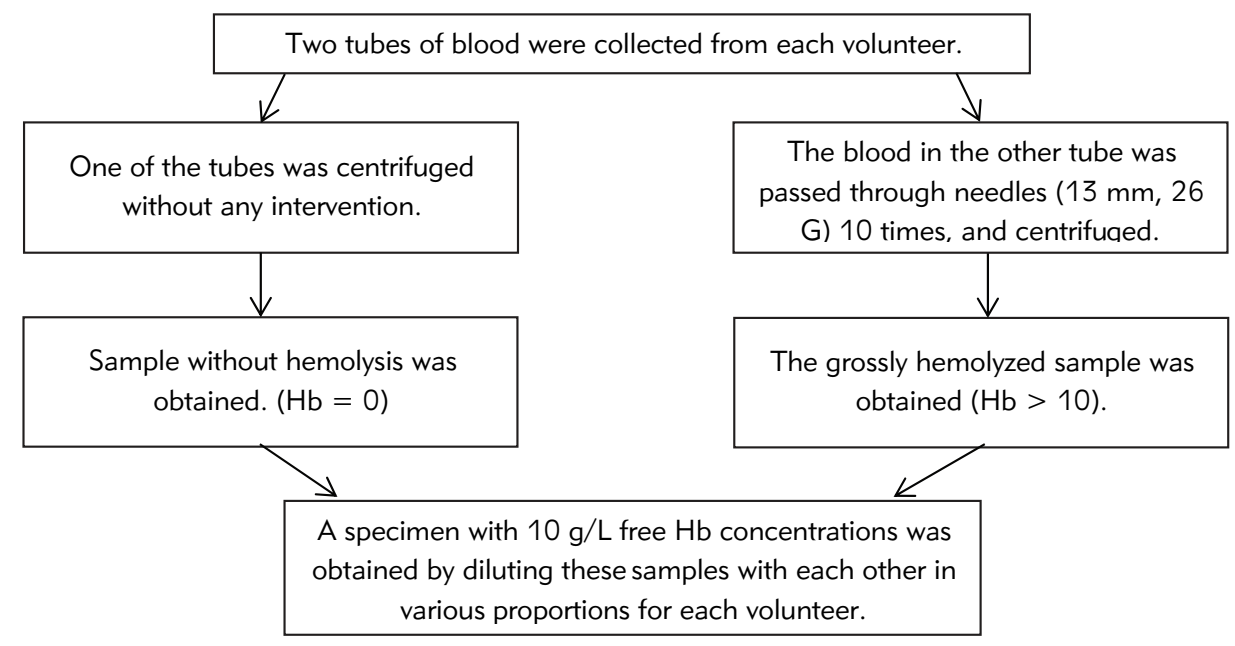

As a result of these processes, two samples

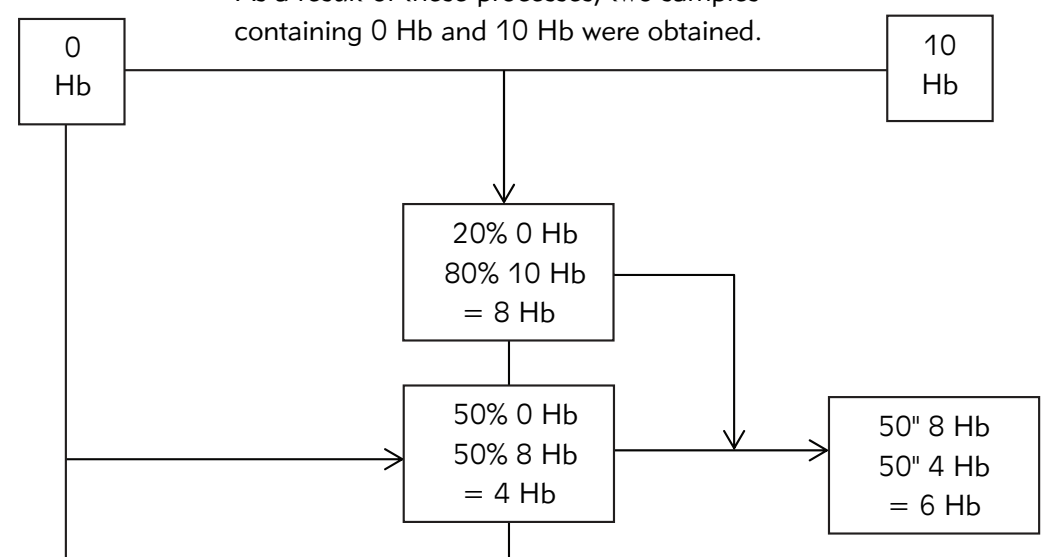

$50 \% 0 \mathrm{Hb}$

$50 \% 4 \mathrm{Hb}$

$=2 \mathrm{Hb}$

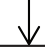

$50 \% 0 \mathrm{Hb}$

$50 \% 2 \mathrm{Hb}$

$=1 \mathrm{Hb}$

Figure 1 Preparation of hemolyzed samples. The samples were prepared individually for each volunteer $(n=10)$. As a result, samples with the desired $\mathrm{Hb}$ concentrations $(0,1,2,4,6,8$, and $10 \mathrm{~g} / \mathrm{L})$ were procured. $\mathrm{Hb}$ was expressed as $\mathrm{g} / \mathrm{L}$. 


\section{Evaluated tests and reagents}

ALT, AST, LDH, K, and T. Bil tests were performed on a Beckman Coulter clinical chemistry analyzer AU680 (Beckman Coulter, Brea, CA). Tests were analyzed in duplicate for each sample. The manufacturer's original reagents were used in this study. The principles of the tests have been elaborated in the subsequent text.

- ALT: IFCC (without pyridoxal phosphate activation)

- AST: IFCC (without pyridoxal phosphate activation)

- LDH: Lactate to pyruvate, IFCC

- $\mathrm{K}$ : Ion-selective electrodes, indirect

- T. Bil: 3,5-dichlorophenyl-diazonium tetrafluoroborate (DPD) with caffeine, and a surfactant

In the technical sheets of reagents, it has been reported that hemolyzed samples should not be used for AST, K, and LDH tests. No $\mathrm{Hb}$ concentration, $\mathrm{H}$-index limit, or bias of interference has been specified. It has been reported that the interference could be up to $10 \%$ in samples with $5 \mathrm{~g} / \mathrm{L}$ free $\mathrm{Hb}$ for $\mathrm{ALT}$ and $0.45 \mathrm{~g} / \mathrm{L}$ free $\mathrm{Hb}$ for $\mathrm{T}$. Bil. $\mathrm{H}$-index values are expressed qualitatively on the Beckmann AU680 analyzer. The cut-off degrees and the corresponding approximate $\mathrm{Hb}$ concentration ranges are presented in Table I.

\section{Statistical analysis}

The percentage difference was calculated for the samples from each patient. Next, the mean percentage differences were calculated for each $\mathrm{Hb}$ concentration using the percentage differences for 10 different volunteers. The

Table I The cut-off degrees and the corresponding approximate hemoglobin $(\mathrm{Hb})$ concentration ranges in Beckmann Coulter AU680 analyzer.

\begin{tabular}{|c|c|}
\hline $\begin{array}{c}\text { Cut-offs specified by } \\
\text { the manufacturer }\end{array}$ & $\begin{array}{c}\text { Approximate free } \mathrm{Hb} \\
\text { concentration ranges }(\mathrm{g} / \mathrm{L})\end{array}$ \\
\hline 0 & $\mathrm{Hb} \leq 0.5$ \\
\hline+ & $0.5<\mathrm{Hb} \leq 1$ \\
\hline++ & $1<\mathrm{Hb} \leq 2$ \\
\hline+++ & $2<\mathrm{Hb} \leq 3$ \\
\hline++++ & $3<\mathrm{Hb} \leq 5$ \\
\hline+++++ & $5<\mathrm{Hb}$ \\
\hline
\end{tabular}

Shapiro-Wilk test was used to evaluate whether the values were normally distributed. All values in our study were distributed normally, and the results are presented as the mean \pm SD. Subsequently, interferograms were plotted for the evaluated tests. The scatter plots and linear regression method were used when creating interferograms, and the $\mathrm{Hb}$ concentrations corresponding to analytical and clinical cut-offs were calculated using the regression equation of the graphs. Analytical cut-offs were determined according to the desirable allowable CV (analytically acceptable imprecision (I $\%)$ ) values of the biological variation (BV) databases. Clinical cut-offs were determined according to the RCV. Intra-individual $\mathrm{CV}\left(\mathrm{CV}_{\mathrm{l}}\right)$ for tests was obtained from the EFLM BV database and Westgard Desirable BV database $(17,18)$. The $\mathrm{Hb}$ concentration for sample rejection was determined to be $10 \mathrm{~g} / \mathrm{L}$ following the recommendation of EFLM (16). The formulas for the calculation are as follows:

Percent difference (\%)

$=\left(\frac{\text { Result of hemolyzed sample }- \text { Result of nonhemolyzed sample }}{\text { Result of nonhemolyzed sample }}\right) \times 100$

$$
I(\%)=0.5 \times C V_{I}
$$

$$
R C V(\%)=\sqrt{2} \times 1.96 \times \sqrt{\left(C V_{A}^{2}+C V_{I}^{2}\right)}
$$

I: Analytically acceptable imprecision

$$
\mathrm{CV}_{\mathrm{A}} \text { : Laboratory analytical CV }
$$

$\mathrm{CV}_{\text {I }}$ : Within-subject BV

For laboratory analytical $\mathrm{CV}\left(\mathrm{CV}_{\mathrm{A}}\right)$ calculation, two levels of internal quality controls (Beckman Coulter Control Serum 1-2, Inc., USA), which were run on 20 different days, were used. The following formula was used for calculation (16):

$$
C V_{A}=\frac{\text { QC Level 1 CV }+ \text { QC Level } 2 C V_{A}}{2}
$$

The calculations were performed, and interferograms were plotted, using MedCalc ${ }^{\circledR}$ Statistical Software version 19.6.4 (MedCalc Software Ltd, Ostend, Belgium) and Microsoft Office 365 (Microsoft Excel Software, Microsoft Corporation, US).

\section{Results}

According to the specified tests using samples with determined $\mathrm{Hb}$ concentrations, mean percentage differ-

Table II Mean percentage differences (\%) between samples from each subject $(n=10)$ for determined hemoglobin (Hb) values, according to the specified tests.

\begin{tabular}{|l|c|c|c|c|c|c|}
\hline Tests & $\mathrm{Hb}=1 \mathrm{~g} / \mathrm{L}$ & $\mathrm{Hb}=2 \mathrm{~g} / \mathrm{L}$ & $\mathrm{Hb}=4 \mathrm{~g} / \mathrm{L}$ & $\mathrm{Hb}=6 \mathrm{~g} / \mathrm{L}$ & $\mathrm{Hb}=8 \mathrm{~g} / \mathrm{L}$ & $\mathrm{Hb}=10 \mathrm{~g} / \mathrm{L}$ \\
\hline $\begin{array}{l}\text { Alanine } \\
\text { aminotransferase, U/L }\end{array}$ & $6.7 \pm 3.5$ & $11.4 \pm 4.2$ & $19.6 \pm 7.6$ & $31.0 \pm 12.3$ & $39.6 \pm 15.6$ & $48.2 \pm 15.3$ \\
\hline $\begin{array}{l}\text { Aspartate } \\
\text { aminotransferase, U/L }\end{array}$ & $46.1 \pm 11.3$ & $83.2 \pm 17.9$ & $162.9 \pm 37.2$ & $253.8 \pm 58.3$ & $354.8 \pm 86.4$ & $458.3 \pm 92.6$ \\
\hline $\begin{array}{l}\text { Lactate } \\
\text { dehydrogenase, U/L }\end{array}$ & $50.7 \pm 24.9$ & $126.9 \pm 45.3$ & $287.7 \pm 83.3$ & $517.1 \pm 102.0$ & $659.6 \pm 152.7$ & $794.3 \pm 163.1$ \\
\hline Potassium, mmol/L & $8.0 \pm 4.7$ & $15.3 \pm 5.1$ & $29.3 \pm 7.8$ & $47.3 \pm 7.5$ & $61.0 \pm 10.8$ & $74.3 \pm 12.5$ \\
\hline Total Bilirubin, mmol/L & $-20.3 \pm 12.6$ & $-51.9 \pm 22.5$ & $-115.4 \pm 45.5$ & $-181.3 \pm 78.6$ & $-247.1 \pm 101.2$ & $-295.2 \pm 110.5$ \\
\hline
\end{tabular}

All values are presented as mean \pm SD (\%). Normal distribution of values was proved by Shapiro-Wilk test $(p>0.05)$. 

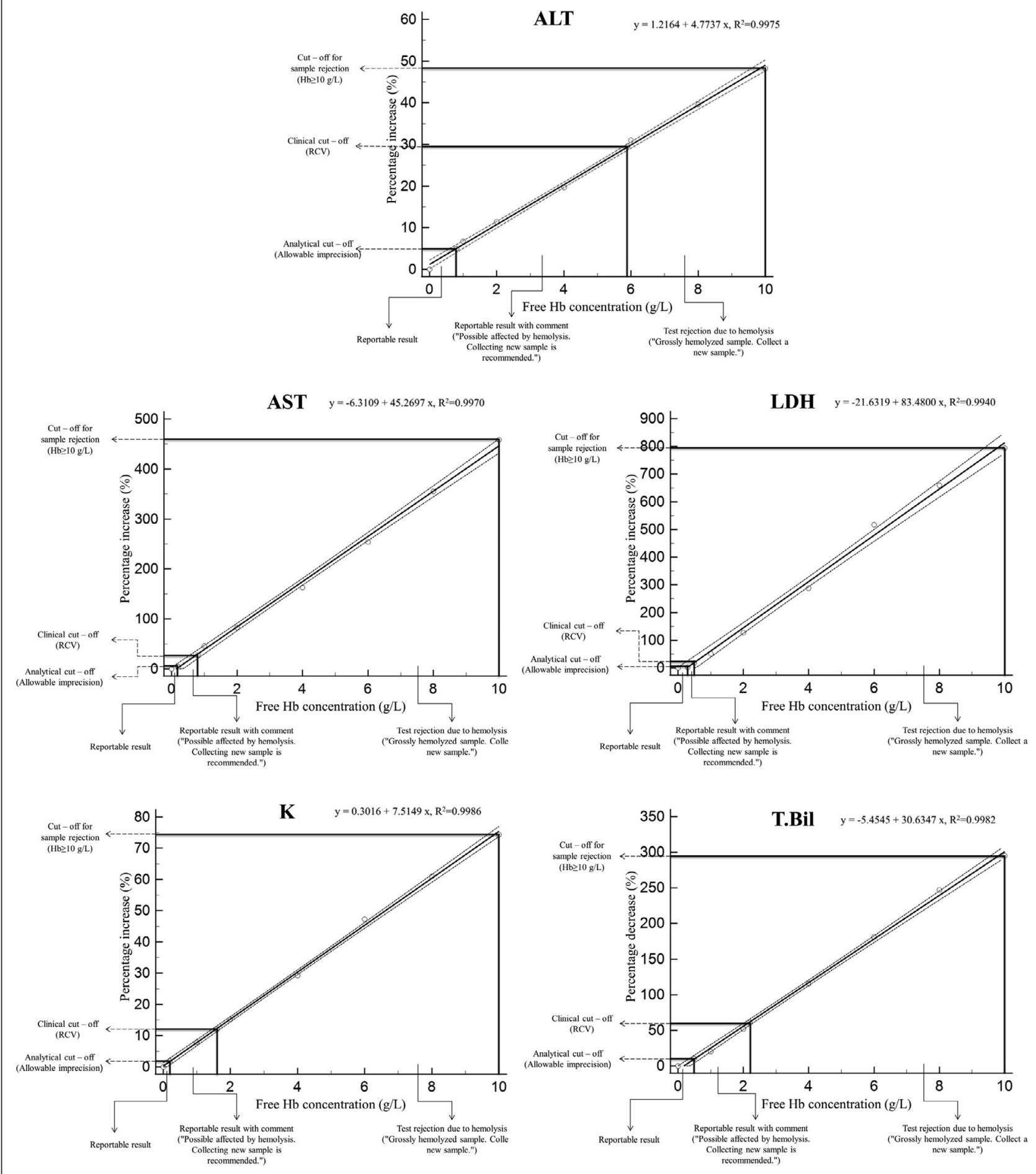

Figure 2 Interferograms of the evaluated tests. Analytical cut-off: desirable allowable imprecision from the biological variation databases, clinical cut-off: reference change value (RCV). Regression equations and coefficient of determinations ( $\left.R^{2}\right)$ are presented in the corners of the figures. The regression line represents the $95 \% \mathrm{Cl}$. Hb: Hemoglobin, ALT: Alanine aminotransferase, AST: Aspartate aminotransferase, K: Potassium, LDH: Lactate dehydrogenase, T. Bil: Total bilirubin. 
Table III Regression equations $(95 \% \mathrm{Cl}), \mathrm{R}^{2}, \mathrm{CV}_{\mathrm{A}}$ and $\mathrm{CV}_{\text {, values }}(\%)$ of the evaluated tests. Analytical and clinical cut-off values (\%) with corresponding free hemoglobin $(\mathrm{Hb})$ concentrations calculated via regression equations.

\begin{tabular}{|c|c|c|c|c|c|c|c|c|}
\hline Tests & $\begin{array}{l}\text { Regression equation } \\
(95 \% \mathrm{Cl})\end{array}$ & $\mathrm{R}^{2}$ & $\begin{array}{l}\mathrm{CV}_{\mathrm{A}} \\
(\%)\end{array}$ & $\begin{array}{l}C V_{1} \\
(\%)\end{array}$ & $\begin{array}{c}\text { Desirable } \\
\text { imprecision } \\
\text { (Analytical cut-off - \%) }\end{array}$ & $\begin{array}{l}\mathrm{Hb}^{\mathrm{a}} \\
(\mathrm{g} / \mathrm{L})\end{array}$ & $\begin{array}{l}\text { RCV (Clinical } \\
\text { cut-off - \%) }\end{array}$ & $\begin{array}{l}\mathrm{Hb}^{\mathrm{b}} \\
(\mathrm{g} / \mathrm{L})\end{array}$ \\
\hline ALT & $\begin{array}{c}y=1.22(-0.33-2.76)+4.77 \\
(4.50-5.05) x\end{array}$ & 0.99 & 3.5 & 10.1 & 5.0 & 0.8 & 29.6 & 5.9 \\
\hline AST & $\begin{array}{c}y=-6.31(-22.25-9.63)+45.27 \\
(42.43-48.11) x\end{array}$ & 0.99 & 3.0 & 9.6 & 4.8 & 0.2 & 27.9 & 0.8 \\
\hline K & $\begin{array}{c}y=0.30(-1.51-2.11)+7.51 \\
(7.19-7.84) x\end{array}$ & 0.99 & 1.5 & 4.1 & 2.0 & 0.2 & 12.1 & 1.6 \\
\hline $\mathrm{LDH}$ & $\begin{array}{c}y=-21.63(-63.39-20.13)+ \\
83.48(76.05-90.91) x\end{array}$ & 0.99 & 4.6 & 5.2 & 2.6 & 0.3 & 19.2 & 0.5 \\
\hline T. BIL & $\begin{array}{c}y=-5.63(-14.83-3.57)+30.66 \\
(29.03-32.30) x\end{array}$ & 0.99 & 3.4 & 21.8 & 10.9 & 0.5 & 61.2 & 2.2 \\
\hline
\end{tabular}

${ }^{a}$ Corresponding to analytical cut-off ${ }^{b}$ Corresponding to clinical cut-off. $\mathrm{Cl}$ : Confidence interval, $\mathrm{R}^{2}$ : Coefficient of determination, $\mathrm{CV}_{\mathrm{A}}$ : Analytical CV of the laboratory, $\mathrm{CV}_{1}$ : Within - subject Biological Variation, Analytical cut-off: Desirable allowable imprecision values from Biological Variation databases, Clinical cut-off: RCV (Reference change value). ALT: Alanine aminotransferase, AST: Aspartate aminotransferase, K: Potassium, LDH: Lactate dehydrogenase, T.Bil: Total bilirubin.

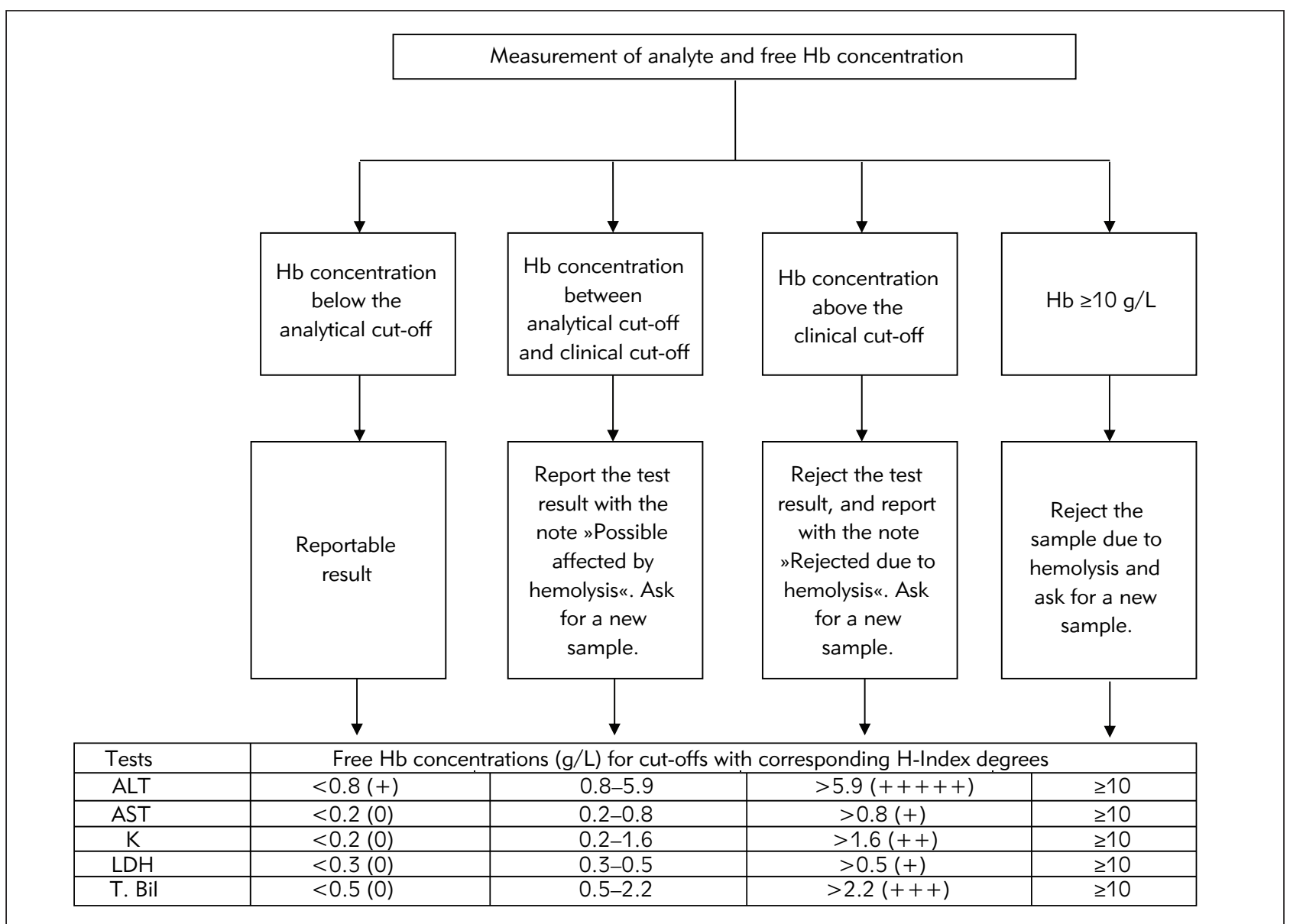

Figure 3 Basic presentation of the composed algorithms. Hb concentrations corresponding to cut-offs were calculated via the regression equation. $\mathrm{H}$-index degrees were adapted to the results in line with the cut-offs of the manufacturer. Hb: Hemoglobin, ALT: Alanine aminotransferase, AST: Aspartate aminotransferase, K: Potassium, LDH: Lactate dehydrogenase, T. Bil: Total bilirubin. 
ences (\%) between the samples are presented in Table II. The interferograms of the tests are shown in Figure 2. The desirable allowable impression (I \%) - analytical cut-off for ALT was obtained as $5.0 \%$. The RCV - clinical cut-off was calculated as $29.6 \%$ (Table III). Hb concentrations corresponding to these values were calculated as 0.8 and 5.9 $\mathrm{g} / \mathrm{L}$ based on the regression equation (Table III). Accordingly, for samples with $\mathrm{Hb}$ concentration $<0.8 \mathrm{~g} / \mathrm{L}$, ALT results could be reported directly; with $0.8-5.9 \mathrm{~g} / \mathrm{L}$, ALT results could be reported with interpretation (Table III). Since the percentage change values of ALT in samples with $\mathrm{Hb}>5.9 \mathrm{~g} / \mathrm{L}$ were greater than the $\mathrm{RCV}$, it was deemed appropriate for rejection (Table III). For AST, LDH, K, and T.Bil, I \% values and RCVs were found to be $4.8 \%, 27.9 \%$; $2 \%, 12.1 \% ; 2.6 \%, 19.2 \%$; and $10.9 \%, 61.2 \%$, respectively (Table III). The Hb concentration cut-offs obtained from the regression equation for the four tests were found to be 0.2 , $0.8 \mathrm{~g} / \mathrm{L} ; 0.2,1.6 \mathrm{~g} / \mathrm{L} ; 0.3,0.5 \mathrm{~g} / \mathrm{L}$, and $0.5,2.2 \mathrm{~g} / \mathrm{L} ;$ respectively (Table III). The $\mathrm{H}$-index measurement results in each hemolyzed sample were observed in agreement with the manufacturer's H-index cut-offs. However, it was observed that the ratio of change in analyte results due to hemolysis did not fully comply with the manufacturer's statements.

The $\mathrm{CV}_{A}, \mathrm{CV}_{\mid}$, analytical cut-off (I) and clinical cut-off values $(R C V)$, regression equations $(95 \% \mathrm{Cl})$, coefficient of determinations $\left(\mathrm{R}^{2}\right)$, and the corresponding $\mathrm{Hb}$ levels to cut-off values are presented in Table III. A simple presentation of the algorithms is shown in Figure 3.

\section{Discussion}

In our study, the hemolysis interference was evaluated for five clinical biochemistry parameters, based on the BV desirable 1\% (analytical cut-off) and RCV\% (clinical cut-off). Accordingly, to determine the extent to which the tests were affected by hemolysis, LDH, AST, K, T. Bil, and ALT tests were performed, with respect to $\mathrm{Hb}$ concentration ranging from low to high.

For $\mathrm{LDH}$, if the $\mathrm{Hb}$ concentration of the sample was $<0.3 \mathrm{~g} / \mathrm{L}$, the test result could be reported directly; moreover, it could be reported with comment for $0.3-0.5 \mathrm{~g} / \mathrm{L}$ $\mathrm{Hb}$, and the test had to be rejected for $>0.5 \mathrm{~g} / \mathrm{L} \mathrm{Hb}$. For AST and $\mathrm{K}$, the corresponding $\mathrm{Hb}$ values (in $\mathrm{g} / \mathrm{L}$ ) were found to be $<0.2,0.2-0.8$, and $>0.8$, and $<0.2,0.2-1.6$, and $>1.6$, respectively (Figure 3 ). As per the manufacturer's recommendation, these three tests should be rejected on the hemolyzed samples. As the initial cut-off value determined by the manufacturer for the $\mathrm{H}$-index is $0.5 \mathrm{~g} / \mathrm{L}$, it can be assumed that the hemolyzed sample was meant for samples containing $0.5 \mathrm{~g} / \mathrm{L} \mathrm{Hb}$. In another study, the upper limit of $\mathrm{Hb}$ reference value for hemolysis-free plasma samples was found to be 0.13 and $0.10 \mathrm{~g} / \mathrm{L}$ in two different biochemistry analyzers (19). Although no information is available in the literature for our device, these values may be considered valid for our study, since it involved working with plasma samples containing lithium heparin. In fact, the $\mathrm{Hb}$ concentrations corresponding to the analytical cut-offs we calculated in our study for LDH, AST, and $\mathrm{K}$ seem close to these values. Besides, the tests most affected by hemolysis were those of LDH, AST, and K. However, our findings - particularly those associated with $\mathrm{K}$ - do not seem entirely consistent with the manufacturer's statement. It has been observed that $\mathrm{K}$ can be analyzed on samples containing up to $1.6 \mathrm{~g} / \mathrm{L} \mathrm{Hb}$.
When the $\mathrm{Hb}$ concentration of the sample for $\mathrm{T}$. Bil was $<0.5 \mathrm{~g} / \mathrm{L}$, the result could be reported directly. It was observed that for $0.5-2.2 \mathrm{~g} / \mathrm{L} \mathrm{Hb}$, the result could be reported with comment and that it should be rejected for $>2.2 \mathrm{~g} / \mathrm{L} \mathrm{Hb}$. For ALT, these $\mathrm{Hb}$ values were found to be $<0.8,0.9-5.9$, and $>5.9$, respectively (Figure 3). The manufacturer stated that the hemolysis interference could be less than $10 \%$ in samples containing $\mathrm{Hb}$ up to $0.45 \mathrm{~g} / \mathrm{L}$ for $\mathrm{T}$. Bil and $5 \mathrm{~g} / \mathrm{L}$ for ALT. Although this information is consistent with our findings, it is insufficient to manage samples containing 0.45 and $5 \mathrm{~g} / \mathrm{L}$ in the T. Bil and ALT, respectively. According to our findings, samples containing up to $2.2 \mathrm{~g} / \mathrm{L}$ and $5.9 \mathrm{~g} / \mathrm{L}$ could be analyzed for T. Bil and ALT, respectively, and the result could be reported with the interpretation.

Perovic and Dolvic (20) evaluated the hemolysis levels of 25 clinical biochemistry parameters using RCV and compared the results with the manufacturer's statements. Similar to our study, the Beckman Coulter AU480 clinical chemistry analyzer and reagents from the same manufacturer were used in this study. It was observed that the findings within the reference range obtained in this study were consistent with our findings, and in the same study, it was stated that the manufacturer's statements were insufficient for ALT tests, among the tests evaluated. Studies on other devices and reagents have also obtained results that do not comply with the manufacturer's declarations (21-24). On the other hand, the general approach assumes the significant change affecting the result as $\pm 10 \%$ and presents the cut-off values accordingly. However, this ratio is far from being a proper criterion for every test (24). Using RCV or other criteria instead of $\pm 10 \%$ change value as a standard for each test can also support their flexibility $(24,25)$. Additionally, rejection rates may decrease by accepting RCV as a cut-off for test rejection (23). Based on these data, the use of RCV and these algorithms by manufacturers while performing interference studies will make the $\mathrm{H}$-Index more beneficial.

Moreover, several problems have been observed with the routine use of the $\mathrm{H}$-index. EFLM WG-PRE had a call for IVD manufacturers to provide more clarity, with respect to serum indexes, in 2018 (26). One problem is that the $\mathrm{H}$ index is reported as degrees in some devices and free $\mathrm{Hb}$ concentrations in other devices. EFLM WG-PRE recommended a harmonization in reporting results via the use of a common unit, free $\mathrm{Hb}(\mathrm{g} / \mathrm{L})$. Another problem is that manufacturers do not adequately report the interference specifications of the kits according to their $\mathrm{H}$-index. For laboratories, inadequate information could be a significant problem in the management of hemolyzed samples. This situation was also evaluated in a large survey study conducted by EFLM WG-PRE, with the participation of 1405 laboratories in 37 European countries. It has been reported that many laboratories indicate heterogeneity of data on interference as the reason for avoiding serum indexes, and 67\% of laboratories using serum indexes use the cut-off values recommended by the manufacturer without verification $(27,28)$. On the other hand, EFLM WG-PRE assumes that IVD producers did not fully comply with CLSI guidelines while performing interference studies; therefore, verification studies should be carried out by the laboratories (28). Furthermore, internal, and external quality control evaluations for $\mathrm{H}$-index are recommended, given the critical importance of $\mathrm{H}$-index results in the evaluation of other test results (26). It is thought that the approaches in which pre- 
analytical variables are considered, especially in external quality control assessments, can provide efficient use of the $\mathrm{H}$-index (12).

Our findings support this point of view. As seen in our study, it is thought that presenting the hemolysis interference with the qualitative cut-offs given based on approximate concentrations recommended by the manufacturer instead of the free $\mathrm{Hb}$ concentrations may be unsatisfactory for the evaluation and interpretation of hemolysis. Moreover, it would be more beneficial to use interferograms, instead of a single cut-off value, for managing hemolyzed samples. Interferograms provide more precise information for testing or sample rejection; hence, they allow laboratories the flexibility to accept the sample, and analyze or reject the tests. It is necessary to be careful when deciding to reject the samples that have been submitted to the laboratory. The decision on which sample is inappropriate, decision on tests that cannot be carried out in these samples, or decision to reject the sample should be based on evidence-based information. The blood sample is submitted to laboratories with the intent to elucidate crucial information about the patient being examined. The importance of correct interpretation of the test results, and their subsequent reporting, by a laboratory professional is analogous to that of accurate interpretation of a physical examination by a physician (29). The laboratory specialist's process for extensive assessment of the sample also includes the determination of which sample is suitable for analyzing or the determination of which test will be carried out. Analyzing the samples and reporting the correct result should be one of the priorities of laboratories due to the prolonged diagnostic process, additional cost, and other problems related to patient/doctor safety that may arise due to incorrect results and rejection (16). When we collectively evaluate these findings and opinions, the use of $\mathrm{H}$-index

\section{References}

1. ISO 22367:2020(en). Medical laboratories - Application of risk management to medical laboratories.

2. Plebani M, Laposata M, Lippi G. Driving the route of laboratory medicine: a manifesto for the future. Intern Emerg Med 2019; 11-4.

3. Plebani M, Carraro P. Mistakes in a stat laboratory: Types and frequency. Clin Chem 1997; 43(8): 1348-51.

4. Carraro P, Plebani M. Errors in a stat laboratory: Types and frequencies 10 years later. Clin Chem 2007; 53(7): 1338-42.

5. Lippi G, von Meyer A, Cadamuro J, Simundic AM. Blood sample quality. Diagn Berl Ger 2019; 6(1): 25-31.

6. Mrazek C, Lippi G, Keppel MH, Felder TK, Oberkofler H, Haschke-Becher $\mathrm{E}$, et al. Errors within the total laboratory testing process, from test selection to medical decisionmaking - A review of causes, consequences, surveillance and solutions. Biochem Medica 2020; 30(2): 1-19.

7. Letelier P, Guzmán N, Medina G, Calcumil L, Huencho P, Mora J, Quiñones F, Jara J, Reyno C, Farías JG, Belén LH, Brebi P, Riquelme I, Martín AS. Workflow optimization in a clinical laboratory using lean management principles in and other serum indexes with interferograms appears to be beneficial for laboratories.

There are some limitations to this study. First, only five parameters affected by hemolysis were selected. A study including all clinical biochemistry tests would yield a more comprehensive result. Second, the reference method for $\mathrm{Hb}$ measurement is the hemoglobin cyanide method measured spectrophotometrically (30). However, the Mindray BC 6800 auto hematology analyzer used in our routine laboratory was used in our study to measure the $\mathrm{Hb}$ value. It is reported in the literature that the device we use is satisfactory in terms of analytical performance for $\mathrm{Hb}$ measurement (31). Nevertheless, using the reference method could provide more accurate results. Finally, the test results we evaluated in our study are within the reference ranges valid for the relevant test. Conducting evaluations in concentrations exceeding the reference range may help use the $\mathrm{H}$ index more effectively.

Therefore, using the $\mathrm{H}$-index with $\mathrm{RCV}$ and adapting the information to interferograms could be advantageous for laboratories to identify and manage hemolyzed samples. Single cut-off values are not suitable for use in interferograms alone. As observed in our study, it seems more appropriate to perform local studies to verify these values and determine the analytical and clinical cut-offs.

Research funding: This research did not receive any specific grant from funding agencies in the public, commercial, or not-for-profit sectors.

\section{Conflict of interest statement}

All the authors declare that they have no conflict of interest in this work.

the pre-analytical phase. J Med Biochem 2021; 40(1): 26-32.

8. Carraro P, Servidio G, Plebani M. Hemolyzed specimens: A reason for rejection or a clinical challenge? Clin Chem 2000; 46(2): 306-7.

9. Abdel Ghafar TM, El-Masry IM. Verification of quantitative analytical methods in medical laboratories. J Med Biochem 2021; 40(3) 225-36.

10. Simundic AM, Nikolac N, Ivankovic V, Ferenec-Ruzic D, Magdic B, Kvaternik $M$, et al. Comparison of visual vs. automated detection of lipemic, icteric and hemolyzed specimens: Can we rely on a human eye? Clin Chem Lab Med 2009; 47(11): 1361-5.

11. Luksic AH, Nikolac Gabaj N, Miler M, Dukic L, Bakliza A, Simundic AM. Visual assessment of hemolysis affects patient safety. Clin Chem Lab Med 2018; 56(4): 57481.

12. Simundic AM, Baird G, Cadamuro J, Costelloe SJ, Lippi $\mathrm{G}$. Managing hemolyzed samples in clinical laboratories. Crit Rev Clin Lab Sci 2020; 57(1): 1-21.

13. Lippi G, Cervellin G, Favaloro EJ, Plebani M. In Vitro and In Vivo Hemolysis: An Unresolved Dispute in Laboratory 
Medicine. Berlin/Boston: Walter de Gruyter $\mathrm{GmbH}$; 2012.

14. CLSI. Hemolysis, Icterus, and Lipemia/Turbidity Indices as Indicators of Interference in Clinical Laboratory Analysis; Approved Guideline. CLSI document C56-A. Wayne, PA: Clinical and Laboratory Standards Institute; 2012.

15. Fraser CG. Test result variation and the quality of evidence-based clinical guidelines. Clin Chim Acta 2004; 346(1): 19-24.

16. Lippi G, Cadamuro J, Von Meyer A, Simundic AM. Practical recommendations for managing hemolyzed samples in clinical chemistry testing. Clin Chem Lab Med 2018; 56(5): 718-27.

17. EFLM Biological Variation Database. Available from: https://biologicalvariation.eu/ Accessed at: 15.06.2020.

18. Westgard Biological Variation Database. Available from: https://www.westgard.com/biodatabase1.htm Accessed at: 15.06.2020.

19. Lippi G, Giavarina D, Gelati M, Salvagno GL. Reference range of hemolysis index in serum and lithium-heparin plasma measured with two analytical platforms in a population of unselected outpatients. Clin Chim Acta 2014 Feb; 429: 143-6.

20. Perovic A, Dolcic M. Influence of hemolysis on clinical chemistry parameters determined with Beckman Coulter tests-detection of clinically significant interference. Scand J Clin Lab Invest 2019; 79(3): 154-9.

21. Monneret D, Mestari F, Atlan G, Corlouer C, Ramani Z, Jaffre $J$, et al. Hemolysis indexes for biochemical tests and immunoassays on Roche analyzers: Determination of allowable interference limits according to different calculation methods. Scand J Clin Lab Invest 2015; 75(2): 162-9.

22. Du Z, Liu JQ, Zhang $H$, Bao BH, Zhao RQ, Jin $Y$. Determination of hemolysis index thresholds for biochemical tests on Siemens Advia 2400 chemistry analyzer. J Clin Lab Anal 2019; 33(4): 1-7.

23. Knezevic CE, Ness MA, Tsang PHT, Tenney BJ, Marzinke MA. Establishing hemolysis and lipemia acceptance thresholds for clinical chemistry tests. Clin Chim Acta 2020; 510(July): 459-65.
24. Gils C, Sandberg MB, Nybo M. Verification of the hemolysis index measurement: imprecision, accuracy, measuring range, reference interval and impact of implementing analytically and clinically derived sample rejection criteria. Scand J Clin Lab Invest 2020; 80(7): 580-9.

25. Koseoglu M, Hur A, Atay A, Cuhadar S. Effects of hemolysis interferences on routine biochemistry parameters. Biochem Medica 2011; 21(1): 79-85.

26. von Meyer A, Cadamuro J, Lippi G, Simundic AM. Call for more transparency in manufacturers declarations on serum indices: On behalf of the Working Group for Preanalytical Phase (WG-PRE), European Federation of Clinical Chemistry and Laboratory Medicine (EFLM). Clin Chim Acta 2018; 484(March): 328-32.

27. Cadamuro J, Lippi G, von Meyer A, Ibarz M, van Dongen-Lases $E$, Cornes $M$, et al. European survey on preanalytical sample handling - Part 1: How do European laboratories monitor the preanalytical phase? On behalf of the European Federation of Clinical Chemistry and Laboratory Medicine (EFLM) Working Group for the Preanalytical Phase. Biochem Medica 2019; 29(2): 20704.

28. Cadamuro J, Lippi G, von Meyer A, Ibarz M, van Dongen-Lases $E$, Cornes $M$, et al. European survey on preanalytical sample handling - part 2: Practices of European laboratories on monitoring and processing haemolytic, icteric and lipemic samples. On behalf of the European federation of clinical chemistry and laboratory medicine (EFLM). Biochem Medica 2019; 29(2): 33445.

29. Lippi G, Plebani M. Integrated diagnostics: The future of laboratory medicine? Biochem Medica 2020; 30(1): 113.

30. CLSI. Reference and Selected Procedures for the Quantitative Determination of Hemoglobin in Blood; Approved Standard-Third Edition. CLSI document H15-A3. Wayne, PA: Clinical and Laboratory Standards Institute; 2000.

31. Lippi G, Cattabiani C, Bonomini S, Bardi M, Pipitone S, Aversa F. Preliminary evaluation of complete blood cell count on Mindray BC-6800. Clin Chem Lab Med 2013; 51(4): 2012-4. 